OPEN ACCESS

Edited by:

Samuel David Crish,

Northeast Ohio Medical University,

United States

Reviewed by:

Rafael Linden,

Universidade Federal do Rio de Janeiro, Brazil

Roland Brandt,

University of Osnabrück, Germany Javier Villadiego,

Universidad de Sevilla, Spain

*Correspondence:

Christoph Handschin

christoph.handschin@unibas.ch

Specialty section:

This article was submitted to

Neurodegeneration,

a section of the journal

Frontiers in Neurology

Received: 29 January 2018

Accepted: 02 August 2018

Published: 24 August 2018

Citation:

Delezie J and Handschin C (2018) Endocrine Crosstalk Between Skeletal

Muscle and the Brain

Front. Neurol. 9:698

doi: 10.3389/fneur.2018.00698

\section{Endocrine Crosstalk Between Skeletal Muscle and the Brain}

\author{
Julien Delezie and Christoph Handschin*
}

Biozentrum, University of Basel, Basel, Switzerland

Skeletal muscle is an essential regulator of energy homeostasis and a potent coordinator of exercise-induced adaptations in other organs including the liver, fat or the brain. Skeletal muscle-initiated crosstalk with other tissues is accomplished though the secretion of myokines, protein hormones which can exert autocrine, paracrine and long-distance endocrine effects. In addition, the enhanced release or uptake of metabolites from and into contracting muscle cells, respectively, likewise can act as a powerful mediator of tissue interactions, in particular in regard to the central nervous system. The present review will discuss the current stage of knowledge regarding how exercise and the muscle secretome improve a broad range of brain functions related to vascularization, neuroplasticity, memory, sleep and mood. Even though the molecular and cellular mechanisms underlying the communication between muscle and brain is still poorly understood, physical activity represents one of the most effective strategies to reduce the prevalence and incidence of depression, cognitive, metabolic or degenerative neuronal disorders, and thus warrants further study.

Keywords: physical exercise, myokines, metabolites, BDNF, PGC- $1 \alpha$, hippocampus, memory, angiogenesis

\section{INTRODUCTION}

\section{Exercise Is Powerful Medicine}

Physicians increasingly encourage patients to exercise through medical prescriptions of specific physical activity programs based on the strong epidemiological link between a sedentary life style and various diseases (1-4). The deleterious effects of physical inactivity often are further exacerbated by excessive calorie intake resulting in obesity $(5,6)$. Nevertheless, a sedentary lifestyle is a strong and independent risk factor for a range of medical conditions such as cardiovascular pathologies, diabetes, certain types of cancer, depression, neurological disorders or stroke, for which the prevalence can be significantly reduced by being active and fit (7-9). However even though the epidemiological evidence is strong, our knowledge of the molecular and cellular mechanisms by which exercise promotes health is still rudimentary.

\section{The Science of Exercise}

In terms of weight, skeletal muscle is the most abundant organ of the human body. Its function encompasses the maintenance of postural support, the generation of force and power during voluntary movements, breathing and thermoregulation. In addition, skeletal muscle accounts for a large portion of oxidative metabolism and of insulin-stimulated glucose uptake. Moreover, as a major storage site for glucose, lipids and amino acids, muscle is an essential coordinator of wholebody energy metabolism. For example, muscle protein metabolism rapidly adapts in response to physical exercise, dietary protein or anabolic hormones such as insulin-like growth factor 1 or testosterone $(10,11)$. The plasticity of skeletal muscle is further illustrated by the myriad of effects 
that either endurance- or resistance-based training induce at the cellular and molecular levels $(12,13)$. Recent observations in rodents and humans have demonstrated the ability of contracting myofibers to produce and release cytokines and other peptides, so-called myokines, which play a crucial role in the skeletal muscle crosstalk with other tissues and, together with musclecontrolled synthesis and degradation of metabolites, represent an essential mechanism to control whole-body homeostasis (14).

\section{EXERCISE RESPONSE AND THE INVOLVEMENT OF MUSCLE PGC-1 $\alpha$}

Exercise rapidly triggers substantial changes at the organismal level depending on various factors, including type, duration and intensity (13). To optimize contractions, the activity of the cardiovascular, respiratory, metabolic and neuroendocrine systems is modulated. At least in part, these adaptations are initiated from muscle tissue, for example by the paracrine release of nitric oxide (NO), ATP or reactive oxygen species (ROS) by myofibers (15). Other changes are mediated by hormonal signaling, e.g., by glucagon, catecholamines or growth hormones. For example, hepatic gluconeogenesis and lipolysis in adipose tissue are stimulated to ensure adequate energy supply to contracting myofibers (16).

In response to exercise, glycolysis products (i.e., lactate, pyruvate), lipolysis products (i.e., glycerol), amino acids (i.e., alanine and glutamine) and ketone bodies (in particular $\beta$ hydroxybutyrate; $\mathrm{BOHB}$ ) are found at higher levels in the circulation $(17,18)$. Some of these metabolites, for example lactate and $\mathrm{BOHB}$, are energy substrates for the central nervous system in the context of limited glucose $(19,20)$. BOHB and lactate transport is mediated by monocarboxylate transporters (MCTs) at the blood-brain barrier (21). Interestingly, exercise has been associated with changes in the expression of such transporters (MCT1, 2 and 4) in the rat cortex and hippocampus

Abbreviations: 3HK, Hydroxykynurenine; AICAR, 5-Aminoimidazole4-carboxamide ribonucleotide; AMPK, AMP-dependent kinase; BAIBA, $\beta$-Aminoisobutyric acid; BDNF, Brain-derived neurotrophic factor; BMAL1, Also known as Aryl hydrocarbon receptor nuclear translocator-like protein 1 (Arntl); BOHB, $\beta$-Hydroxybutyrate; CREB, Cyclic-AMP-responsive-elementbinding protein; CTSB, Cathepsin B; CXCL-1, CXC ligand 1; DCX, Doublecortin; ER, Endoplasmic reticulum; ERK1/2, Extracellular signal-regulated kinase; ERR $\alpha$, Estrogen-related receptor $\alpha$; FABP, Fatty-acid-binding protein; FGF21, Fibroblast growth factor 21; FNDC5, Fibronectin type III domain-containing protein 5; FXR, Farnesoid X receptor; GLUT4, Glucose transporter 4; HCAR, Hydroxycarboxylic acid receptors; HDAC, Histone deacetylase; IGF-1, Insulin-like growth factor 1; IL, Interleukin; KAT, kynurenine aminotransferase; KYN, Kynurenine; KYNA, Kynurenic acid; LCN2, Lipocalin 2; LIF, Leukemia inhibitory factor; LXRs, Liver $\mathrm{X}$ receptor; MC4R, Melanocortin 4 receptor; MCT, Monocarboxylate transporter; mTOR, Mechanistic target of rapamycin; NO, Nitric oxide; NREM, Non-rapid eye movement; NRF, Nuclear respiratory factor; OPA1, mitochondrial fusion protein optic atrophy 1; PGC-1 $\alpha$, Peroxisome-proliferator activated receptor $\gamma$ coactivator $1 \alpha$; PI3K/Akt: Phosphatidylinositol 3-kinase/Akt; PKA, Protein kinase A; PPAR, Peroxisome-proliferator activated receptor; QUIN, Quinolinic acid; REV-ERB $\alpha$, also known as nuclear receptor subfamily 1 group D member 1 (Nr1d1); ROR $\alpha$, RAR-related orphan receptor alpha; ROS, Reactive oxygen species; RXR, Retinoid $\mathrm{X}$ receptor; SIRT1, Silent mating type information regulation 2 homolog; SPP1, Secreted phosphoprotein 1; TrkB, Tropomyosin receptor kinase B; VEGF, Vascular endothelial growth factor.
(22). Notably, lactate and BOHB are not only metabolic fuels for neuronal cells, but also bind the hydroxycarboxylic acid receptors (HCARs) and behave as signaling molecules at the central level (23). For instance, lactate influences neuronal activity, calcium signaling, axonal myelination, angiogenesis and memory formation $(24,25)$. The most abundant free amino acid in the human body, glutamine, essential as metabolic fuel and a protein building block, is a potent regulator of multiple signaling pathways related to inflammation, cell integrity and metabolism $(26,27)$. Interestingly, an elevation of glutamine in the rat hippocampus, striatum, and cerebellum following endurance exercise has recently been demonstrated (28). However, since the brain is autonomous for the production of glutamine and the blood-brain barrier rather impermeable to this amino acid, a redistribution from skeletal muscle in this context is rather unlikely (29). Lastly, it is important to highlight the metabolic coupling between neuronal and glial cells. In particular, prolonged exercise diminishes brain glycogen essentially stored in astrocytes providing lactate to adjacent neurons $(30,31)$. This lactate shuttle from astrocytes to neurons has been implicated in long-term memory formation (32), and has been shown to influence endurance capacity (33).

Exercise-induced cellular stress (e.g., ATP and $\mathrm{O}_{2}$ depletion, $\mathrm{Ca}^{2+}$ elevation, changes in the $\mathrm{NADH} / \mathrm{NAD}^{+}$ratio and mechanical stress) leads to the activation of multiple signaling pathways in skeletal muscle (16). Therefore, exercise is not only a potent modifier of the metabolome as previously discussed, but also affects the muscle epigenome, transcriptome and proteome (34-39). A marked acute exercise-induced hypomethylation of the promoters of the peroxisome-proliferator activated receptor $\gamma$ coactivator $1 \alpha$ (PGC-1 $\alpha)$ and the peroxisome-proliferator activated receptor $\delta(\mathrm{PPAR} \beta / \delta)$ in human muscle (34) parallels an upregulation of PGC- $1 \alpha$ mRNA and protein stability, in part via PPAR $\delta$-dependent mechanisms $(40-43)$. This PGC- $1 \alpha-$ PPAR $\delta$ axis plays a pivotal role in the regulation of muscle mitochondrial metabolism in the initial phase of exercise, and mediates the increase in mitochondrial biogenesis essential for endurance training adaptation. Importantly, PGC- $1 \alpha$ acts as a central regulator of mitochondrial dynamics by recruiting and co-regulating multiple transcription factors including the nuclear respiratory factors NRF-1 and NRF-2, PPAR $\alpha$ and PPAR $\delta$, and the estrogen-related receptor $\alpha(\mathrm{ERR} \alpha)(44-46)$. The PGC-1 $\alpha$ $\mathrm{ERR} \alpha$ association is essential to coordinate lactate homeostasis during muscle contraction (47) and mediates exercise-induced angiogenesis through the induction of VEGF $(48,49)$. The active coordination of muscle angiogenesis by PGC- $1 \alpha$ is further illustrated by its ability to induce the release of the secreted phosphoprotein 1 (SPP1), which recruits macrophages to help orchestrate multicellular angiogenesis (50). PGC- $1 \alpha$ can also promote remodeling at the neuromuscular junction, which may be mediated by the secretion of neurturin $(51,52)$. Overall, PGC- $1 \alpha$ integrates various cell signals during exercise.

The exercise-induced perturbations in the muscle milieu also lead to the activation of upstream kinases e.g., AMPactivated protein kinase (AMPK) and deacetylases e.g., SIRT1, that functionally interact with PGC- $1 \alpha(53,54)$. AMPK is a conserved energy sensor that is present in all mammalian cells, 
specifically activated in conditions that elevate the AMP:ATP ratio, with exercise being one of the most powerful activators of AMPK especially in human muscles (55). Acute exercise induces AMPK phosphorylation and enzymatic activity in an intensitydependent manner, which in turn stimulates ATP production by promoting glucose transport and fatty-acid oxidation (16). Noteworthy, peripheral administration of the AMPK agonist AICAR can enhance running endurance capacity in sedentary mice. Likewise, a PPAR $\delta$ agonist (GW501516) induces a gene program in skeletal muscle related to oxidative metabolism similar to endurance exercise (56). Whether these and related compounds are real "exercise mimetics" remains debatable (57). Intriguingly, treatment of wild-type mice with AICAR, and to a lesser extent with GW501516, enhances spatial memory and elevates neurogenesis in the hippocampal dentate gyrus area, again similar to exercise (58). Surprisingly, the effect of AICAR on memory function and hippocampal plasticity is dependent on the expression of the AMPK $\alpha 2$-subunit in muscle cells, providing evidence for a muscle-mediated mechanism (59).

\section{THE WHEEL OF HEALTH: NEUROTROPHIC AND GROWTH FACTORS}

In humans, the neurobiological effects of exercise are numerous e.g., reduction of anxiety and depression, improvement of social skills and self-esteem as well as mood and cognitive abilities $(60,61)$, in concert with significant structural changes at the central level (62-64). Voluntary exercise in a running wheel promotes neurogenesis and long-term potentiation in the adult rodent dentate gyrus $(65,66)$. Transcriptomic studies have described changes in gene categories related to chromatin remodeling, neuronal signaling and plasticity, protein synthesis and trafficking, and the inflammatory/immune response in rodent hippocampus after running [reviewed in (67)].

Importantly, one hallmark of physical activity is the central and peripheral induction of the brain-derived neurotrophic factor (BDNF). BDNF is a secretory growth factor belonging to the family of neurotrophins, which supports neural survival, growth, and synaptic plasticity. BDNF can signal via both TrkB and $\mathrm{p} 75^{\mathrm{NTR}}$ receptors (68-71) and is induced in the hippocampus of exercised rats (72). Inhibition of the action of BDNF in the central nervous system results in a reduction of the recruitment of the cAMP response-element-binding protein (CREB) to target sites on genes that mediate the exercise-induced enhancement in learning and memory (73). Moreover, there is evidence that physical activity in humans also elevates the level of circulating BDNF $(74,75)$. Similarly, BDNF brain and blood levels also correlate in other species i.e., pigs, rats, and humans (76). Notably, besides the brain as a potential source, a substantial amount of circulating BDNF originates from megakaryocytes, precursors of blood platelets; hence, the variations in BDNF in exercise studies could be caused by the different activation level of human platelets (77). The contribution of platelets to the exercise effects, in particular on the brain, remains unexplored (78), even though BDNF could be transported in plateletderived vesicles to the brain (79). Unlike human megakaryocytes, this cell population is not involved in BDNF synthesis in the mouse (77). In contrast, BDNF is produced and secreted by human and rodent skeletal muscles and is regulated by exercise $(80,81)$. Muscle BDNF seems mostly involved in autocrine and paracrine signaling to promote muscle fiber fat oxidation and potentially muscle development (81-83), as well as in the retrograde signaling on motor neurons located in the spinal cord (84). Whether muscle-derived BDNF also signals to the brain, e.g., via TrkB signaling at the blood-brain barrier (85), remains to be investigated.

The blood-brain barrier consists of endothelial cells, vascular smooth cells, pericytes, basement membranes and astrocytic feet along cerebral microvessels, regulating the exchange between blood and neural tissue. This neurovascular interface acts as a barrier, limiting or facilitating the entry of specific nutrients, metabolites and hormones. For example, the hormone insulinlike growth factor-1 (IGF-1), mainly produced by the liver, can cross the blood-brain barrier and act as a mediator of the exercise-induced changes in hippocampal neurogenesis and BDNF expression $(86,87)$. Importantly, the formation and maintenance of dendritic spines in hippocampal neurons in basal conditions depend on the BDNF-dependent induction of PGC- $1 \alpha$ after exercise $(88,89)$. In neuronal tissue, PGC- $1 \alpha$ is a potent suppressor of ROS and thus exerts neuroprotective effects (90). Interestingly, long-term voluntary running exercise can slow down the progression of some neurodegenerative or age-related central deteriorations in mice (91-93). This is consistent with data emerging from human studies, in which aerobic exercise moderately prevents or delays the onset of aging- and neurodegeneration-associated memory loss (9496). Noteworthy, neurogenesis in rodents occurs within an angiogenic niche (97) and exercise-induced vascularization is mediated in part by circulating vascular endothelial growth factor [VEGF; (98)]. Moreover, peripheral blockade of VEGF abolishes running-induced neurogenesis (99). Importantly, other neurotrophic factors are regulated by physical exercise in rodents. For instance, the expression of the glial cell line-derived neurotrophic factor or neurotrophin-3 is affected by physical exercise in skeletal muscle, the spinal cord, or the brain (100103). These results thus suggest that molecules other than BDNF could also mediate the neuroprotective effects of physical exercise at the central level [discussed in (104)].

Altogether, a combination of blood-born factors and centrallyexpressed genes is required to promote angiogenesis and neurogenesis at the central level. Future studies are needed to characterize how IGF-1, VEGF and, putatively, BDNF signaling is integrated by neurons, and how exercise impacts the endothelial and glial cell populations at the blood-brain interface.

\section{FROM SKELETAL MUSCLE TO THE BRAIN: INVOLVEMENT OF MYOKINES AND METABOLITES}

Since the discovery of interleukin-6 (IL-6) as a cytokine produced by and released from skeletal muscle (105), various other exercise-induced factors have been identified by biochemical (106-108), proteomic $(109,110)$, or transcriptomic approaches 
(106, 111). These factors, called myokines, have autocrine, paracrine and/or endocrine effects [for review, see $(14,112)$ ]. Importantly, the muscle secretome is not limited to protein hormones, as muscle cells also release or remove circulating metabolites. For instance, forced overexpression of PGC$1 \alpha$ in myocytes triggers the production and release of $\beta$ aminoisobutyric acid (BAIBA), which modulates both liver and fat metabolism (113). In this review, we focus on the recently described mediators of the muscle-to-brain communication (Table 1).

\section{Irisin}

In 2002, two studies reported the discovery of a cDNA encoding a novel protein, PeP/Frcp2, now named FNDC5 $(124,125)$. The secreted form of FNDC5, irisin, is a PGC- $1 \alpha$-dependent myokine induced by exercise (126). Noteworthy, irisin circulates at levels close to essential metabolic hormones (e.g., insulin, leptin) in humans (127), and acts on subcutaneous fat, promoting the beigeing and thermogenic program of white adipocytes, thereby increasing energy expenditure $(126,128)$. Moreover, irisin has the potential to modulate muscle and liver cell metabolism in vitro [reviewed in (129)]. Interestingly, FNDC5 has been detected in different areas of the brain $(124,125)$ and has been associated with neural differentiation (130). Additional evidence implies that FNDC5/irisin is also a part of the transcriptional response to exercise in the mouse hippocampus along with PGC- $1 \alpha$ and BDNF (89). Mechanistically, the study demonstrated that the PGC- $1 \alpha$-dependent induction of FNDC5 in both primary cortical and hippocampal neurons involves the transcription factor ERR $\alpha$. Moreover, FNDC5 is required to induce BDNF in a cell-autonomous manner, and recombinant BDNF treatment decreased FNDC5 expression as a part of a negative feedback loop. Most strikingly, the elevation of circulating levels of irisin by adenoviral overexpression of FNDC5 in the liver increased BDNF expression in the mouse hippocampus, but not in the forebrain.

Collectively, these data reveal a cellular mechanism by which endurance exercise promotes hippocampal gene expression such as BDNF and PGC- $1 \alpha$ related to neuroprotection and memory. While it is unclear whether peripheral or central irisin mediate these effects in the brain, the adenoviral overexpression raises the possibility that circulating irisin could cross the blood-brain barrier, or act on receptors expressed by endothelial cells, to further amplify the effect of exercise on the central nervous system. In that regard, the deletion of FNDC5 in brain or skeletal muscle cells, together with the identification of its receptor, may delineate the exact contribution of systemic vs. local/central irisin. This seems especially important as modulation of central vs. peripheral irisin levels differently affects blood pressure in rodents (131).

\section{Cathepsin B}

The cysteine protease cathepsin B (CTSB) is ubiquitously expressed throughout the body, including human muscle cells during exercise $(109,132)$. In the search of muscle-produced factors using a mass spectrometry-based approach, Moon et al. (114) exposed rat myotubes to the AMPK agonist AICAR and identified CTSB as a putative myokine. The authors further demonstrated that short-term AICAR treatment was effective in inducing $C t s b$ mRNA in myotubes. Moreover, 30 days of wheelrunning activity upregulated $C t s b$ mRNA in the hippocampus and the gastrocnemius muscle (but not in other organs e.g., liver or adipose tissue), as well as plasma levels of CTSB in mice. Likewise, 4 months of treadmill exercise led to a significant increase of plasma CTSB concentrations in rhesus monkeys and humans. Furthermore, Moon et al. (114) showed that CTSB has the property to cross the blood-brain barrier and the application of exogenous CTSB to hippocampal progenitor cells induced both BDNF and doublecortin (DCX) transcripts. Strikingly, physical activity did not promote hippocampal neurogenesis or improved spatial memory in whole-body CTSB KO mice, suggesting that central and/or muscle-derived CTSB could mediate the beneficial effects of physical activity on memory function in rodents. Whether a correlation between human plasma CTSB levels and fitness or memory scores exists, as suggested by the authors, remains to be confirmed. Likewise, it is not clear if a therapeutic elevation of blood CTSB levels would be sufficient to enhance hippocampal-dependent memory function, especially in the aging context. Besides, the physiological effects of chronic exogenous CTSB administration have to be addressed, in particular in light of its involvement in inflammation, cell apoptosis, tumor development and progression $(133,134)$. Lastly, the signaling pathway by which peripheral and/or central CTSB promotes BDNF elevation and neurogenesis is still unknown.

\section{L-Lactate}

A recent study has uncovered a cellular mechanism by which blood-born lactate from contracting muscles signals to the brain to promote angiogenesis. Morland et al. (115) investigated the putative role the hydroxycarboxylic acid receptor 1 (HCAR1), enriched at the blood-brain barrier (135), as a mediator of lactate-induced central vascularization. They observed that after 7 weeks of wheel-running activity, mice lacking HCAR1 did not show increased VEGFA expression and capillary density in the dentate gyrus or the sensorimotor cortex. Similarly, chronic subcutaneous injections of sodium L-lactate failed to enhance VEGFA expression and vascularization in HCAR1 KO animals, indicating that HCAR1 is essential to mediate the effects of exercise on angiogenesis in specific brain areas. Moreover, in line with the involvement of the phosphatidylinositol 3-kinase/Akt (PI3K/Akt) and extracellular signal-regulated kinase (ERK1/2) signaling pathways in mediating the induction of VEGF (136), both lactate and a selective HCAR1 agonist failed to activate ERK1/2 and Akt in hippocampal slices lacking HCAR1. The authors further defined the location of the HCAR1 protein in the leptomeningeal fibroblast-like cells of the pia mater-the innermost layer of the meninges which supports blood vesselas well as pericyte-like cells, previously shown to be involved in the control of blood flow and angiogenesis (137).

\section{Kynurenin and Kynurenic Acid}

The underlying cause of depression is difficult to elucidate as a combination of biological, psychological and environmental factors contribute to the pathogenesis of this disease. Notably however, depressed patients are usually less physically active, 
TABLE 1 | Overview of muscle-derived and exercise-induced endocrine signals involved in the periphery-brain crosstalk.

\begin{tabular}{|c|c|c|c|c|c|c|}
\hline $\begin{array}{l}\text { Protein or } \\
\text { metabolite }\end{array}$ & Tissue & Experimental models & $\begin{array}{l}\text { Detected } \\
\text { in blood }\end{array}$ & $\begin{array}{l}\text { Transport/ } \\
\text { receptor }\end{array}$ & Central effects & $\begin{array}{l}\text { Main } \\
\text { references }\end{array}$ \\
\hline \multicolumn{7}{|c|}{ IDENTIFIED AND PUTATIVE MUSCLE-DERIVED FACTORS TRIGGERED BY EXERCISE } \\
\hline L-Lactate & Skeletal muscle & $\begin{array}{l}\text { HCAR1 KO mice } \\
\text { Exogenous L-lactate injection }\end{array}$ & $\begin{array}{l}\text { Human } \\
\text { Mouse }\end{array}$ & $\begin{array}{l}\text { MCTs/HCAR1 } \\
\text { at the BBB }\end{array}$ & $\begin{array}{l}\uparrow \text { Vascularization } \\
\uparrow \text { VEGFA expression and } \\
\text { vascularization }\end{array}$ & (115) \\
\hline$?$ & Skeletal muscle & $\begin{array}{l}\text { Peripheral AICAR injection } \\
\text { Deletion of the AMPK } \alpha 2 \text {-subunit } \\
\text { in mouse muscle }\end{array}$ & ? & $?$ & $\begin{array}{l}\uparrow \text { Hippocampal neurogenesis + } \\
\text { spatial memory }\end{array}$ & $(58,59)$ \\
\hline \multicolumn{7}{|c|}{ ADDITIONAL FACTORS (NOT NECESSARILY INDUCED BY PHYSICAL ACTIVITY OR DERIVED FROM SKELETAL MUSCLE) } \\
\hline$\beta$-hydroxybutyrate & Liver (fasting + PA) & $\begin{array}{l}\text { Exercise mouse } \\
\text { Central } \beta \text {-hydroxybutyrate } \\
\text { injection } \\
\text { shRNA-mediated KD of HDAC3 }\end{array}$ & $\begin{array}{l}\text { Human } \\
\text { Mouse }\end{array}$ & $\begin{array}{l}\text { MCTs and } \\
\text { HCARs at the } \\
\text { BBB }\end{array}$ & $\begin{array}{l}\downarrow \text { HDAC2 and HDAC3 } \\
\text { recruitment at Bdnf promoters } \\
\uparrow \text { Hippocampal BDNF } \\
\uparrow \text { Glutamate release }\end{array}$ & $(116)$ \\
\hline $\begin{array}{l}\text { Fibroblast growth } \\
\text { factor } 21\end{array}$ & $\begin{array}{l}\text { Liver (PA) } \\
\text { Adipose Skeletal } \\
\text { muscle }\end{array}$ & $\begin{array}{l}\text { Peripheral and central FGF21 } \\
\text { injection } \\
\text { Overexpression of FGF21 in } \\
\text { mouse liver } \\
\text { Deletion of } \beta \text {-Klotho in mouse } \\
\text { brain }\end{array}$ & $\begin{array}{l}\text { Human } \\
\text { Mouse }\end{array}$ & $\begin{array}{l}\text { BBB } \\
\text { crossing//KIlotho, } \\
\text { FGFR1 }\end{array}$ & $\begin{array}{l}\text { Regulation of metabolism, } \\
\text { energy expenditure, and } \\
\text { circadian behavior }\end{array}$ & $(117-119)$ \\
\hline$?$ & Skeletal muscle & $\begin{array}{l}\text { Mouse global, brain- or } \\
\text { muscle-specific } \\
\text { deletion/overexpression of } \\
\text { BMAL1 }\end{array}$ & ? & $?$ & $\begin{array}{l}\text { Regulation of NREM sleep time } \\
\text { and sleep recovery following } \\
\text { sleep deprivation }\end{array}$ & $(123)$ \\
\hline
\end{tabular}

BBB, blood-brain barrier; PA, physical activity.

and the effectiveness of exercise programs in reducing depressive symptoms has been widely recognized $(138,139)$. Kynurenine $(\mathrm{KYN})$ is a metabolite of the amino acid L-tryptophan, primarily synthetized in the liver. The degradation of KYN follows two different pathways: one proceeds with the conversion of KYN to 3-hydroxykynurenine $(3 \mathrm{HK})$ and quinolinic acid (QUIN), while the alternative pathway converts $\mathrm{KYN}$ to kynurenic acid (KYNA). In the brain, the conversion to KYNA is catalyzed by kynurenine aminotransferases (KATs) found in astrocytes. The same enzymes are expressed in different peripheral tissues including skeletal muscle $(140,141)$. Importantly, evidence suggests that a dysregulation of the KYN pathway is associated with a number of psychiatric disorders such as depression $(140,141)$. In a study from Agudelo et al. (121), exercise has been shown to activate the expression of KATs through a PGC- $1 \alpha$ - and PPAR $\alpha / \delta$ dependent pathway in both mouse and human muscles. Consistently, overexpression of PGC- $1 \alpha$ and loss of PGC$1 \alpha$, respectively, resulted in increased and decreased muscle KAT expression levels. The increase in KATs expression in the gain-of-function model shifted KYN metabolism toward enhanced synthesis of KYNA, which is unable to cross the blood-brain barrier, thereby reducing the accumulation of plasma KYN with its neurotoxic effects on the brain. Remarkably, this shift conferred resistance to chronic mild stress-induced depression in mice overexpressing PGC-1 $\alpha$ in their muscles. 
The authors furthermore demonstrated that muscle PGC$1 \alpha$ elevation prevented the alterations in the expression of neurotrophic, synaptic and pro-inflammatory markers in the hippocampus in response to chronic mild stress and, to a lesser extent, exogenous KYN administration. These data suggest that physical exercise could also affect neuroinflammation [reviewed in $(142,143)]$.

These findings further illustrate how muscle PGC- $1 \alpha$ can mediate the benefits of exercise in the crosstalk between skeletal muscle and the brain. Incidentally, a new observation in healthy individuals confirmed that regular endurance training promotes skeletal muscle KATs gene and protein expression, along with enhanced peripheral conversion of KYN to KYNA (122). Moreover, the "detoxifying" potential of skeletal muscle may not be limited to KYNA, as muscle PGC- $1 \alpha$ also regulates systemic ketone body levels and can prevent hyperketosis (144).

\section{$\beta$-Hydroxybutyrate}

The transcriptional regulation of BDNF in the hippocampus at least in part depends on the modulation of histone acetylation (145). By comparing sedentary mice to mice that had runningwheel access for 30 days, Sleiman et al. (116) found that exercise induced changes in class I HDAC expression, a family of proteins that suppress gene expression by deacetylating lysine residues on histone and non-histone proteins. In particular, binding of HDAC2 and HDAC3 to the hippocampal Bdnf promoter I and II was reduced in exercising mice, leading to elevated BDNF levels. Interestingly, besides its role as energy source, the ketone body $\mathrm{BOHB}$ also acts as an epigenetic signaling molecule by inhibiting class I HDACs (23). Sleiman and colleagues hypothesized that this exercise factor might inhibit the action of the histone deacetylases on the $B d n f$ promoter. They showed that exercise induces $\mathrm{BOHB}$ accumulation in the hippocampus and that the direct injection of $\mathrm{BOHB}$ into the ventricles of mice led to higher BDNF expression. In addition, application of BOHB to primary neurons decreased HDAC3 binding to the $B d n f$ promoter, whereas the use of a selective HDAC3-inhibitor or the knockdown of HDAC3 by shRNA increased BDNF expression. This effect on BDNF expression appeared specific, as BOHB did not induce $P g c-1 \alpha$, Fndc5, or Err $\alpha$ mRNA in primary neurons. The authors also found that the increase of BDNF by BOHB led to enhanced glutamate release in hippocampal slices, and that this effect was dependent on TrkB signaling. The potential of $\mathrm{BOHB}$ to convey peripheral information to the brain is further illustrated by other findings demonstrating that liver-derived BOHB modulates neural network-based prediction of feeding time in mice (146).

\section{Muscle Bmal1}

Sleep is a critical health function that is controlled by complex mechanisms distributed in multiple brain areas such as the cortex, the brain stem and the hypothalamus (147). Circadian clocks are located in nearly every cell of the mammalian body and generate molecular rhythms with a 24 -h period, essential to adjust the behavior and physiology of an organism to the external environment (148). In the past, several studies in mice and humans have demonstrated the consequence of genetic clock perturbations on sleep homeostasis $(149,150)$. In particular, global deletion of the core clock gene Bmal1 in mice can affect sleep processes, with longer non-rapid eye movement (NREM) sleep time and altered sleep response after a period of sleep loss (151). Recent findings from Ehlen et al. (123) have challenged the common view that sleep is a process that is only influenced by the brain. They found that restoring Bmall expression in the brain of whole-body Bmal1 KO mice failed to normalize NREM sleep amount to control values, suggesting that Bmal1 in another tissue might be important to regulate sleep physiology. Indeed, rescuing Bmal1 in skeletal muscle was sufficient to restore NREM sleep amount as well as sleep recovery after sleep loss. A causative role for muscle Bmal1 was further supported by the fact that Bmall deletion only in skeletal muscle recapitulated the sleep alterations seen in whole-body Bmal1 $\mathrm{KO}$ mice, whereas overexpression of Bmal1 in skeletal muscle of wild-type mice renders mice resistant to sleep deprivation.

These results are intriguing for several reasons. First, they suggest for the first time that a single gene in a peripheral tissue can modulate essential centrally-generated sleep processeswhether this depends on the BMAL1 association with CLOCK or other partners in muscle cells has to be investigated. Second, these data imply a muscle-to-brain signaling involved in sleep regulation, either humoral, or, based on the observation that mice lacking Bmall in their muscles exhibit potent metabolic disruptions $(152,153)$, via metabolites. Third, because restoring Bmal1 expression in muscle cells does not restore circadian rhythmicity (154), and more importantly here, the diurnal rhythm of NREM sleep, it is possible that the production and secretion of this muscle-derived factor is a time-controlled cellular event. In the same line of thought, it would be interesting to evaluate whether scheduled exercise, in addition to muscle Bmal1 reintroduction, is able to reinstate sleep phase timing in this mouse model.

\section{PUTATIVE CANDIDATES, NETWORK AND FUTURE RESEARCH}

\section{Cytokines}

Contraction-induced release of IL- 6 has potent effects on wholebody glucose disposal (105). Interestingly, IL-6 can act locally on muscle cell glucose uptake and fatty acid oxidation in an autocrine/paracrine manner (155). Systemic elevation of IL-6 by exogenous administration or exercise stimulates insulin release from pancreatic cells (156) and mediates fasting-induced free fatty acid mobilization by adipose tissue (157) as an endocrine hormone. Importantly, other cytokines, e.g., IL-8 and IL-15 mRNA, are also upregulated upon exercise in skeletal muscle and have the potential to behave as myokines [reviewed in (112)]. Additional evidence suggests that the murine chemokine CXC ligand 1 (CXCL-1) and the leukemia inhibitory factor (LIF)-belonging to the IL-6 cytokine superfamily-are both produced by contracting muscle cells and may exert local or long-distance actions [reviewed in (158)]. Likewise, in vitro data from primary human myotubes further suggest a broader muscle cytokines response to exercise (108). Interestingly, most of these 
cytokines are neuromodulators when expressed by neurons and glial cells, potentially influencing brain health and disease (159). This is especially evidenced in the context of higher central or peripheral level of pro-inflammatory cytokines, which reduce central BDNF expression and thus impact on neurogenesis and neurotransmitter release $(160,161)$. It is currently unclear whether all of these cytokines are released from muscle fibers or from resident immune cells in this tissue. Moreover, a potential crosstalk between muscle and brain remains to be shown: potentially, cytokine signaling at the blood-brain interface might be important to modulate aspects of brain physiology such as sleep, memory or feeding behavior.

\section{FGF21}

Fibroblast growth factor 21 (FGF21) is an endocrine hormone expressed by several tissues including skeletal muscle, adipose tissue and pancreas. The main source of FGF21 is the liver during prolonged fasting, presumably via PPAR $\alpha$ - and PGC-1 $\alpha$ dependent mechanisms, resulting in a modulation of systemic energy balance, insulin sensitivity, hepatic gluconeogenesis and glucocorticoid levels (162). Importantly, FGF21 can cross the blood-brain barrier and is found in both human and mouse cerebrospinal fluid $(163,164)$. Moreover, FGF21 signals in the brain through its co-receptor, $\beta$ Klotho, as well as the FGF receptor-1, located in the hypothalamus $(117,162)$. Proposed effects for FGF21 in the nervous system are the modulation of the sympathetic nerve input to brown adipose tissue, the control of circadian behavior, and neuroprotection $(117,119,165)$. Studies also suggest that FGF21 can be produced by muscle cells in certain context involving e.g., the activation of AKT or the mTORC1 pathway (166-169). Pereira et al. (170) demonstrated that a muscle deficiency of the mitochondrial fusion protein optic atrophy 1 (OPA1) alters mitochondrial dynamics and increases endoplasmic reticulum (ER) stress, thereby promoting muscle-FGF21 release and rendering mice resistant to ageand diet-induced obesity and insulin resistance. The molecular mechanism by which ER-stress activates FGF21 is not clear, but could involve the transcriptional co-regulator PGC- $1 \alpha(171,172)$. Of interest, one study showed increase serum FGF21 levels in mice and humans after exercise, yet likely of liver and not skeletal muscle or adipose tissue origin (118). In summary, FGF21 can be considered as an hepatokine, adipokine, and potentially a myokine, and has various effects at the wholebody level including the nervous system. Thereby, future research should investigate the putative involvement of FGF21 in the muscle-brain crosstalk, especially during exercise.

\section{Inter-cell Crosstalk}

Skeletal muscle is a part of a larger system which also encompasses bones, tendons, ligaments, cartilage, joints, nervous and connective tissues. In particular, beyond their mechanical coupling, bone and muscle cells can communicate at the biochemical and molecular levels underlining a potential paracrine/endocrine crosstalk. Different studies demonstrated an effect of muscle-specific gene deletion or overexpression on bone physiology [reviewed in $(173,174)]$, and a close correlation between bone and muscle deterioration during aging
(175). As in other cell types, different bone cell types have the capacity to release factors into the circulation (176). For instance, the osteoblast-secreted protein osteocalcin is essential to regulate energy metabolism by increasing insulin sensitivity via the stimulation of adiponectin release by adipocytes (177). Intriguingly, mouse and human data showed that circulating osteocalcin levels are increased upon exercise, and greatly diminished during aging. Moreover, bone-derived osteocalcin signals to muscle cells and favors the uptake and utilization of glucose and fatty acids in addition to stimulate muscle secretion of IL-6, which again feedbacks to bone cells to enhance osteocalcin production (178). Mosialou et al. (179) revealed that the bone-derived glycoprotein lipocalin 2 (LCN2), a previously identified component of the immune response (180), crosses the blood-brain barrier and binds to the melanocortin 4 receptor (MC4R) in the paraventricular and ventromedial neurons of the hypothalamus to inhibit food intake. Lipocalin 2 is also produced in muscle cells under the control of PGC-1 $\alpha$ (181).

These findings implicate crosstalk of skeletal muscle with more dispersed peripheral cells. For instance, physical exercise induces the secretion of the adipose-derived hormone adiponectin, which enhances hippocampal neurogenesis and has potent antidepressant effects (182). Interestingly, a role for muscle IL-15 has been suggested in the regulation of adiponectin production (183).

\section{The Circadian Muscle Secretome}

Circadian clocks control myriad of processes such as gene regulation, protein synthesis and export, enzyme activity, cell signaling, nutrient accumulation, on a 24-h time scale. Moreover, clock proteins are cellular sensors, in that they can integrate specific changes in the external or internal environment (184). Chronic circadian disruption by irregular sleep-wake cycles or meal timing has been associated with obesity and other metabolic conditions, cancer and inflammation, sleep as well as cognitive and mental disorders (185-188). In skeletal muscle, the molecular clock has been linked to cell growth and repair, autophagy, insulin sensitivity, lipid homeostasis, mitochondrial metabolism and respiration (152, 189-191). Moreover, scheduled exercise is a potent stimulus to regulate circadian timing in skeletal muscle $(192,193)$. Interestingly, human primary myotubes harbor a cell-autonomous circadian clock involved in the basal release of cytokines (e.g., IL-6, IL-8) and other proteins (e.g., VEGF, FABP) as identified by ELISA and multiplex assays (194). Intriguingly, $P g c-1 \alpha$ transcript oscillates in skeletal muscle and PGC- $1 \alpha$ can co-activate ROR $\alpha$ to induce the expression of Bmall in primary hepatocytes (195). Furthermore, genetic ablation of Bmal1 from muscle cells gave evidence that a peripheral clock function is essential for centrally-controlled sleep processes (123). Thereby, it is likely that a transcriptional regulatory network, involving circadian nuclear receptors and the coactivator protein PGC-1 $\alpha$ coordinates the time-of-daydependent accumulation of myokines in muscle cells and secretion into the circulation. Future work should for instance evaluate the temporal phase relationship between core clock components and muscle-derived factors. Moreover, if part of the muscle secretome is gated by the circadian clock as in other 
endocrine organs (196), there are certainly time windows during which exercise can exert maximal effects on brain physiology.

Altogether, there is a likely bidirectional influence between circadian and exercise pathways in muscle cells-whether this is important for skeletal muscle endocrine function requires further investigation. In any case, at the organismal level, circadian clocks clearly provide a molecular basis by which endocrine signalingi.e., from the production and secretion of an endocrine factor to the activation of a signaling pathway - can be achieved in a timely fashion. Given the conserved relation between circadian clock and neuronal function (197-201), time-based physical activity interventions may potentiate the health benefits of exercise.

\section{CONCLUSION}

Genetic engineering and the relentless motivation of captive rodents to be active on an exercise wheel have given scientists the opportunity to identify several muscle-derived signaling factors (Figure 1). At the central level, BDNF is a crucial mediator of the effects of exercise for the modulation of synaptic transmission, neurogenesis and memory function. In skeletal muscle, PGC- $1 \alpha$ exerts a strong "detoxifying" potential and is an effective regulator of the muscle secretome, essential for exercise adaptations and the regulation of central function such as memory and mood. However, the timing and regulation of myokine production and secretion are still poorly understood. For many putative myokines, a thorough characterization and validation is still lacking [discussed in (14)]. Moreover, discrepancies in the identification of putative myokines have been emerging in studies in cellbased compared to in vivo models (202). Finally, for most of these factors it is unclear whether peripheral or central production is mediating the beneficial effects on the brain. Nevertheless, the strong epidemiological evidence of exercise as a powerful intervention to prevent and treat various pathologies warrants a careful dissection of the signals, networks and

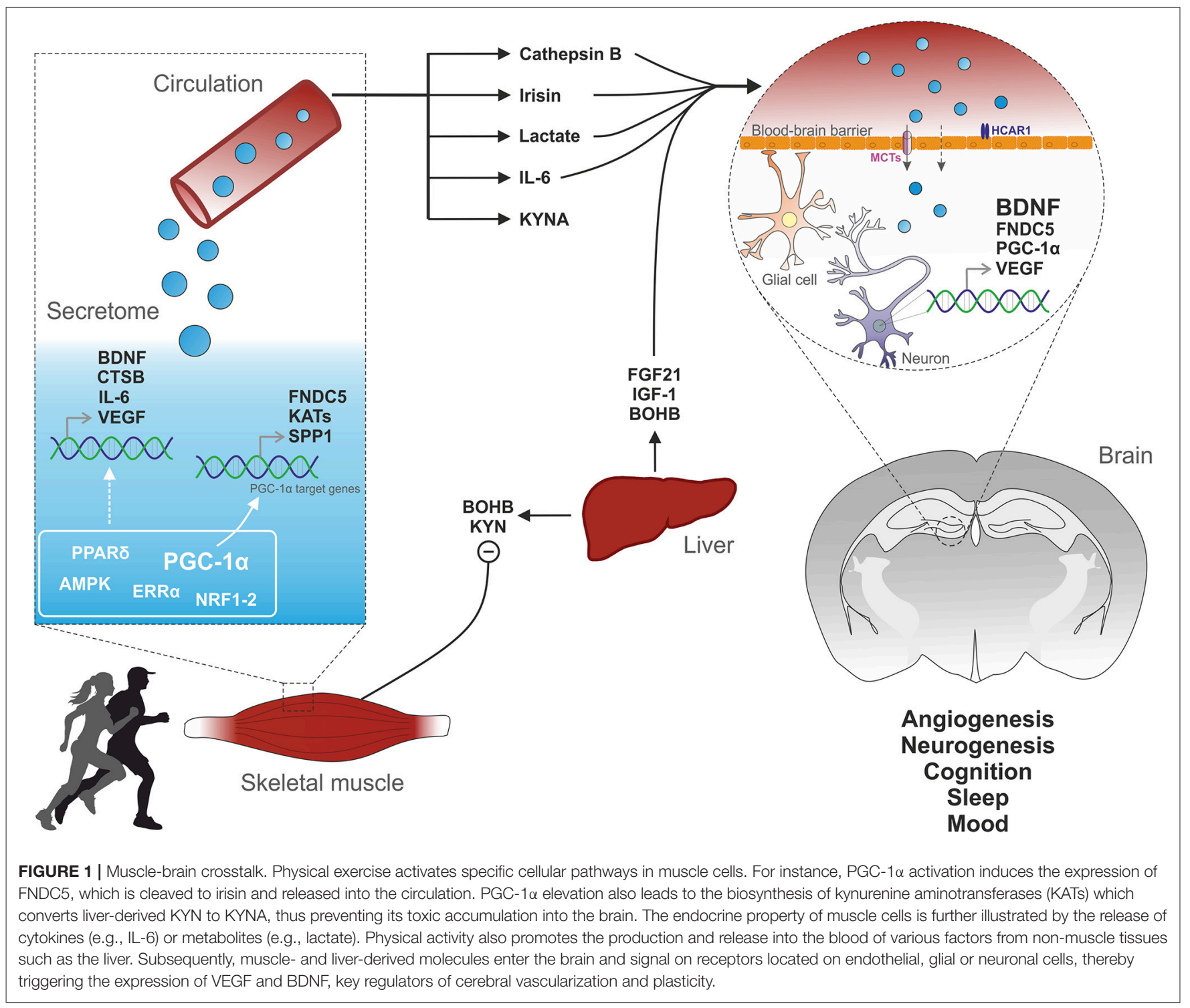


mediators of the inter-organ crosstalk originating from skeletal muscle. This is of particular importance for neurological disorders, where therapeutic options are scarce and desperately needed.

\section{AUTHOR CONTRIBUTIONS}

All authors listed have made a substantial, direct and intellectual contribution to the work, and approved it for publication.

\section{REFERENCES}

1. Ding D, Lawson KD, Kolbe-Alexander TL, Finkelstein EA, Katzmarzyk PT, van Mechelen W, et al. The economic burden of physical inactivity: a global analysis of major non-communicable diseases. Lancet (2016) 388:1311-24. doi: 10.1016/S0140-6736(16)30383-X

2. Lobelo F, Stoutenberg M, Hutber A. The exercise is medicine global health initiative: a 2014 update. Br J Sports Med. (2014) 48:1627-33. doi: 10.1136/bjsports-2013-093080

3. Pedersen BK, Saltin B. Exercise as medicine - evidence for prescribing exercise as therapy in 26 different chronic diseases. Scand J Med Sci Sports (2015) 25 (Suppl. 3):1-72. doi: 10.1111/sms.12581

4. Sallis RE. Exercise is medicine and physicians need to prescribe it! Br J Sports Med. (2009) 43:3-4. doi: 10.1136/bjsm.2008.054825

5. NCD Risk Factor Collaboration (2017). Worldwide trends in bodymass index, underweight, overweight, and obesity from 1975 to 2016: a pooled analysis of 2416 population-based measurement studies in 128.9 million children, adolescents, and adults. Lancet 390, 2627-2642. doi: 10.1016/S0140-6736(17)32129-3

6. Lobstein T, Baur L, Uauy R. Obesity in children and young people: a crisis in public health. Obesity Rev. (2004) 5:4-85. doi: 10.1111/j.1467-789X.2004.00133.x

7. Ekelund U, Steene-Johannessen J, Brown WJ, Fagerland MW, Owen N, Powell KE, et al. Does physical activity attenuate, or even eliminate, the detrimental association of sitting time with mortality? A harmonised metaanalysis of data from more than 1 million men and women. Lancet (2016) 388:1302-10. doi: 10.1016/S0140-6736(16)30370-1

8. Handschin C, Spiegelman BM. The role of exercise and PGClalpha in inflammation and chronic disease. Nature (2008) 454:463-9. doi: $10.1038 /$ nature07206

9. Warburton DE, Nicol CW, Bredin SS. Health benefits of physical activity: the evidence. CMAJ (2006) 174:801-9. doi: 10.1503/cmaj.051351

10. Koopman, R., and van Loon, L. J. Aging, exercise, and muscle protein metabolism. J Appl Physiol. (1985) (2009) 106:2040-8. doi: 10.1152/japplphysiol.91551.2008

11. Rooyackers OE, Nair KS. Hormonal regulation of human muscle protein metabolism. Annu Rev Nutr. (1997) 17:457-85. doi: 10.1146/annurev.nutr.17.1.457

12. Bassel-Duby R, Olson EN. Signaling pathways in skeletal muscle remodeling. Annu Rev Biochem. (2006) 75:19-37. doi: 10.1146/annurev.biochem.75.103004.142622

13. Hawley JA, Hargreaves M, Joyner MJ, Zierath JR. Integrative biology of exercise. Cell (2014) 159:738-49. doi: 10.1016/j.cell.2014.10.029

14. Whitham M, Febbraio MA. The ever-expanding myokinome: discovery challenges and therapeutic implications. Nat Rev Drug Discov. (2016) 15:719-29. doi: 10.1038/nrd.2016.153

15. Sylow L, Kleinert M, Richter EA, Jensen TE. Exercise-stimulated glucose uptake - regulation and implications for glycaemic control. Nat Rev Endocrinol. (2017) 13:133-48. doi: 10.1038/nrendo.2016.162

16. Egan B, Zierath JR. Exercise metabolism and the molecular regulation of skeletal muscle adaptation. Cell Metab. (2013) 17:162-84. doi: 10.1016/j.cmet.2012.12.012

17. Henriksson J. Effect of exercise on amino acid concentrations in skeletal muscle and plasma. J Exp Biol. (1991) 160:149-65.

\section{FUNDING}

The work in our laboratory is funded by the Swiss National Science Foundation, the European Research Council (ERC) Consolidator grant 616830-MUSCLE_NET, Swiss Cancer Research grant KFS-3733-08-2015, the Swiss Society for Research on Muscle Diseases (SSEM), SystemsX.ch, the Novartis Stiftung für Medizinisch-Biologische Forschung and the University of Basel.

18. Lewis GD, Farrell L, Wood MJ, Martinovic M, Arany Z, Rowe GC, et al. Metabolic signatures of exercise in human plasma. Sci Transl Med. (2010) 2:33ra37. doi: 10.1126/scitranslmed.3001006

19. Schurr A. Lactate: the ultimate cerebral oxidative energy substrate? J Cereb Blood Flow Metab. (2006) 26:142-52. doi: 10.1038/sj.jcbfm.9600174

20. van Hall G, Stromstad M, Rasmussen P, Jans O, Zaar M, Gam C, et al. Blood lactate is an important energy source for the human brain. J Cereb Blood Flow Metab. (2009) 29:1121-9. doi: 10.1038/jcbfm.2009.35

21. Bergersen LH. Lactate transport and signaling in the brain: potential therapeutic targets and roles in body-brain interaction. J Cereb Blood Flow Metab. (2015) 35:176-85. doi: 10.1038/jcbfm.2014.206

22. Takimoto M, and Hamada T. Acute exercise increases brain region-specific expression of MCT1, MCT2, MCT4, GLUT1, and COX IV proteins. J Appl Physiol. (2014).116:1238-50. doi: 10.1152/japplphysiol.01288.2013

23. Newman JC, Verdin E. $\beta$-Hydroxybutyrate: a signaling metabolite. Annu Rev Nutr. (2017) 37:51-76. doi: 10.1146/annurev-nutr-071816-064916

24. Barros LF. Metabolic signaling by lactate in the brain. Trends Neurosci. (2013) 36:396-404. doi: 10.1016/j.tins.2013.04.002

25. Ruan GX, Kazlauskas A. Lactate engages receptor tyrosine kinases Axl, Tie2, and vascular endothelial growth factor receptor 2 to activate phosphoinositide 3-kinase/Akt and promote angiogenesis. J Biol Chem. (2013) 288:21161-72. doi: 10.1074/jbc.M113.474619

26. Brasse-Lagnel C, Lavoinne A, Husson A. Control of mammalian gene expression by amino acids, especially glutamine. Febs $j$ (2009) 276:1826-44. doi: 10.1111/j.1742-4658.2009.06920.x

27. Curi R, Newsholme P, Procopio J, Lagranha C, Gorjao R, Pithon-Curi TC. Glutamine, gene expression, and cell function. Front Biosci J Virtual Libr. (2007) 12:344-57. doi: 10.2741/2068

28. Swiatkiewicz M, Fiedorowicz M, Orzeł J, Wełniak-Kaminska M, Bogorodzki $\mathrm{P}$, Langfort J, et al. Increases in brain 1H-MR glutamine and glutamate signals following acute exhaustive endurance exercise in the rat. Front Physiol. (2017) 8:19. doi: 10.3389/fphys.2017.00019

29. Hawkins RA. The blood-brain barrier and glutamate. Am J Clin Nutr. (2009) 90:867S-74S. doi: 10.3945/ajcn.2009.27462BB

30. Machler P, Wyss MT, Elsayed M, Stobart J, Gutierrez R, von Faber-Castell A, et al. In vivo evidence for a lactate gradient from astrocytes to neurons. Cell Metab. (2016) 23:94-102. doi: 10.1016/j.cmet.2015.10.010

31. Matsui $\mathrm{T}$, Ishikawa $\mathrm{T}$, Ito $\mathrm{H}$, Okamoto $\mathrm{M}$, Inoue $\mathrm{K}$, Lee $\mathrm{MC}$, et al. Brain glycogen supercompensation following exhaustive exercise. J Physiol. (2012) 590:607-16. doi: 10.1113/jphysiol.2011.217919

32. Suzuki A, Stern SA, Bozdagi O, Huntley GW, Walker RH, Magistretti PJ, et al. Astrocyte-neuron lactate transport is required for long-term memory formation. Cell (2011) 144:810-23. doi: 10.1016/j.cell.2011.02.018

33. Matsui T, Omuro H, Liu Y-F, Soya M, Shima T, McEwen BS, et al. Astrocytic glycogen-derived lactate fuels the brain during exhaustive exercise to maintain endurance capacity. Proc Natl Acad Sci USA. (2017) 114:635863. doi: 10.1073/pnas.1702739114

34. Barres R, Yan J, Egan B, Treebak JT, Rasmussen M, Fritz T, et al. Acute exercise remodels promoter methylation in human skeletal muscle. Cell Metab. (2012) 15:405-11. doi: 10.1016/j.cmet.2012.01.001

35. Camera DM, Burniston JG, Pogson MA, Smiles WJ, Hawley JA. Dynamic proteome profiling of individual proteins in human skeletal muscle after a high-fat diet and resistance exercise. Faseb J. (2017) 31:5478-94. doi: 10.1096/fj.201700531R 
36. Choi S, Liu X, Li P, Akimoto T, Lee SY, Zhang M, et al. Transcriptional profiling in mouse skeletal muscle following a single bout of voluntary running: evidence of increased cell proliferation. J Appl Physiol. (2005) 99:2406-15. doi: 10.1152/japplphysiol.00545.2005

37. Hody S, Leprince P, Sergeant K, Renaut J, Croisier JL, Wang $F$, et al. Human muscle proteome modifications after acute or repeated eccentric exercises. Med Sci Sports Exerc. (2011) 43:2281-96. doi: 10.1249/MSS.0b013e318222edf3

38. Laker RC, Garde C, Camera DM, Smiles WJ, Zierath JR, Hawley JA, et al. Transcriptomic and epigenetic responses to short-term nutrient-exercise stress in humans. Sci Rep. (2017) 7:15134. doi: 10.1038/s41598-017-15420-7

39. Lundberg TR, Fernandez-Gonzalo R, Tesch PA, Rullman E, Gustafsson T. Aerobic exercise augments muscle transcriptome profile of resistance exercise. Am J Physiol Regul Integr Comp Physiol. (2016) 310:R1279-87. doi: 10.1152/ajpregu.00035.2016

40. Koh JH, Hancock CR, Terada S, Higashida K, Holloszy JO, Han DH. PPARbeta Is Essential for maintaining normal levels of PGC-1alpha and mitochondria and for the increase in muscle mitochondria induced by exercise. Cell Metab. (2017) 25:1176-85.e1175. doi: 10.1016/j.cmet.2017.04.029

41. Perez-Schindler J, Svensson K, Vargas-Fernandez E, Santos G, Wahli W, Handschin C. The coactivator PGC-1alpha regulates skeletal muscle oxidative metabolism independently of the nuclear receptor PPARbeta/delta in sedentary mice fed a regular chow diet. Diabetologia (2014) 57:2405-12. doi: 10.1007/s00125-014-3352-3

42. Schuler M, Ali F, Chambon C, Duteil D, Bornert JM, Tardivel A, et al. PGC1alpha expression is controlled in skeletal muscles by PPARbeta, whose ablation results in fiber-type switching, obesity, and type 2 diabetes. Cell Metab. (2006) 4:407-14. doi: 10.1016/j.cmet.2006.10.003

43. Wright DC, Han DH, Garcia-Roves PM, Geiger PC, Jones TE, Holloszy JO. Exercise-induced mitochondrial biogenesis begins before the increase in muscle PGC-1alpha expression. J Biol Chem. (2007) 282:194-9. doi: 10.1074/jbc.M606116200

44. Kupr B, Handschin C. Complex coordination of cell plasticity by a PGC-1 $\alpha$ controlled transcriptional network in skeletal muscle. Front Physiol. (2015) 6:325. doi: 10.3389/fphys.2015.00325

45. Kupr B, Schnyder S, Handschin C. Role of nuclear receptors in exerciseinduced muscle adaptations. Cold Spring Harb Perspect Med. (2017) 7:a029835. doi: 10.1101/cshperspect.a029835

46. Schnyder S, Kupr B, Handschin C. Coregulator-mediated control of skeletal muscle plasticity - a mini-review. Biochimie (2017) 136:49-54. doi: 10.1016/j.biochi.2016.12.011

47. Summermatter S, Santos G, Pérez-Schindler J, Handschin C. Skeletal muscle PGC-1 $\alpha$ controls whole-body lactate homeostasis through estrogen-related receptor $\alpha$-dependent activation of LDH B and repression of LDH A. Proc Natl Acad Sci USA (2013) 110:8738-43. doi: 10.1073/pnas.1212976110

48. Arany Z, Foo SY, Ma Y, Ruas JL, Bommi-Reddy A, Girnun G, et al. HIF-independent regulation of VEGF and angiogenesis by the transcriptional coactivator PGC-1alpha. Nature (2008) 451:1008-12. doi: $10.1038 /$ nature 06613

49. Chinsomboon J, Ruas J, Gupta RK, Thom R, Shoag J, Rowe GC, et al. The transcriptional coactivator PGC-1alpha mediates exercise-induced angiogenesis in skeletal muscle. Proc Natl Acad Sci USA (2009) 106:21401-6. doi: 10.1073/pnas.0909131106

50. Rowe GC, Raghuram S, Jang C, Nagy JA, Patten IS, Goyal A, et al. PGC- $1 \alpha$ induces SPP1 to activate macrophages and orchestrate functional angiogenesis in skeletal muscle. Circ Res. (2014) 115:504-17. doi: 10.1161/CIRCRESAHA.115.303829

51. Arnold AS, Gill J, Christe M, Ruiz R, McGuirk S, St-Pierre J, et al. Morphological and functional remodelling of the neuromuscular junction by skeletal muscle PGC-1 $\alpha$. Nat Commun (2014) 5:3569. doi: 10.1038/ncomms4569

52. Mills R, Taylor-Weiner H, Correia JC, Agudelo LZ, Allodi I, Kolonelou C, et al. Neurturin is a PGC-1 $1 \alpha 1$-controlled myokine that promotes motor neuron recruitment and neuromuscular junction formation. Mol Metab. (2017) 7:12-22. doi: 10.1016/j.molmet.2017.11.001

53. Jäger S, Handschin C, St.-Pierre J, and Spiegelman BM. AMPactivated protein kinase (AMPK) action in skeletal muscle via direct phosphorylation of PGC-1 $\alpha$. Proc Natl Acad Sci. (2007) 104:12017-22. doi: 10.1073/pnas.0705070104

54. Nemoto S, Fergusson MM, Finkel T. SIRT1 functionally interacts with the metabolic regulator and transcriptional coactivator PGC-1 $\alpha$. J Biol Chem. (2005) 280:16456-60. doi: 10.1074/jbc.M501485200

55. Richter EA, Ruderman NB. AMPK and the biochemistry of exercise: implications for human health and disease. Biochem J. (2009) 418:261-75. doi: 10.1042/BJ20082055

56. Fan W, Waizenegger W, Lin CS, Sorrentino V, He M-X, Wall CE, et al. PPAR $\delta$ promotes running endurance by preserving glucose. Cell Metab. (2017) 25:1186-93.e1184. doi: 10.1016/j.cmet.2017.04.006

57. Handschin C. Caloric restriction and exercise "mimetics": ready for prime time? Pharmacol Res. (2016) 103:158-66. doi: 10.1016/j.phrs.2015.11.009

58. Kobilo T, Yuan C, van Praag H. Endurance factors improve hippocampal neurogenesis and spatial memory in mice. Learn Mem. (2011) 18:103-7. doi: $10.1101 / \mathrm{lm} .2001611$

59. Kobilo T, Guerrieri D, Zhang Y, Collica SC, Becker KG, van Praag H. AMPK agonist AICAR improves cognition and motor coordination in young and aged mice. Learn Mem. (2014) 21:119-26. doi: 10.1101/lm.033332.113

60. Peluso MAM, Guerra de Andrade LH. Physical activity and mental health: the association between exercise and mood. Clinics (2005). 60:61-70. doi: 10.1590/S1807-59322005000100012

61. Taylor CB, Sallis JF, Needle R. The relation of physical activity and exercise to mental health. Public Health Rep. (1985) 100:195-202.

62. Erickson KI, Voss MW, Prakash RS, Basak C, Szabo A, Chaddock L, et al. Exercise training increases size of hippocampus and improves memory. Proc Natl Acad Sci USA. (2011) 108:3017-22. doi: 10.1073/pnas.1015950108

63. Firth J, Stubbs B, Vancampfort D, Schuch F, Lagopoulos J, Rosenbaum $S$, et al. Effect of aerobic exercise on hippocampal volume in humans: a systematic review and meta-analysis. NeuroImage (2018) 166:230-8. doi: 10.1016/j.neuroimage.2017.11.007

64. Sexton CE, Betts JF, Demnitz N, Dawes H, Ebmeier KP, JohansenBerg H. A systematic review of MRI studies examining the relationship between physical fitness and activity and the white matter of the ageing brain. Neuroimage (2016) 131:81-90. doi: 10.1016/j.neuroimage.2015.0 9.071

65. van Praag H, Christie BR, Sejnowski TJ, Gage FH. Running enhances neurogenesis, learning, and long-term potentiation in mice. Proc Natl Acad Sci USA. (1999) 96:13427-31. doi: 10.1073/pnas.96.23.13427

66. van Praag H, Kempermann G, Gage FH. Running increases cell proliferation and neurogenesis in the adult mouse dentate gyrus. Nat Neurosci. (1999) 2:266-70. doi: $10.1038 / 6368$

67. Eisinger $\mathrm{BE}$, Zhao $\mathrm{X}$. Identifying molecular mediators of environmentally enhanced neurogenesis Cell Tissue Res. (2018). 371:7-21. doi: 10.1007/s00441-017-2718-5

68. Bramham CR, Messaoudi E. BDNF function in adult synaptic plasticity: the synaptic consolidation hypothesis. Prog Neurobiol. (2005) 76:99-125. doi: 10.1016/j.pneurobio.2005.06.003

69. Lu B, Nagappan G, Lu Y. BDNF and synaptic plasticity, cognitive function, and dysfunction. In: Lewin GR, Carter BD, editors. Neurotrophic Factors. Berlin; Heidelberg: Springer (2014), p. 223-50.

70. Matsumoto T, Rauskolb S, Polack M, Klose J, Kolbeck R, Korte M, et al. Biosynthesis and processing of endogenous BDNF: CNS neurons store and secrete BDNF, not pro-BDNF. Nat Neurosci. (2008) 11:131-3. doi: $10.1038 / \mathrm{nn} 2038$

71. Yang J, Siao CJ, Nagappan G, Marinic T, Jing D, McGrath K, et al. Neuronal release of proBDNF. Nat Neurosci. (2009) 12:113-5. doi: 10.1038/nn.2244

72. Neeper SA, Góauctemez-Pinilla F, Choi J, Cotman C. Exercise and brain neurotrophins. Nature (1995) 373:109. doi: 10.1038/373109a0

73. Vaynman S, Ying Z, Gomez-Pinilla F. Hippocampal BDNF mediates the efficacy of exercise on synaptic plasticity and cognition. Eur J Neurosci. (2004) 20:2580-90. doi: 10.1111/j.1460-9568.2004.03720.x

74. Rasmussen P, Brassard P, Adser H, Pedersen MV, Leick L, Hart E, et al. Evidence for a release of brain-derived neurotrophic factor from the brain during exercise. Exp Physiol. (2009) 94:1062-9. doi: 10.1113/expphysiol.2009.048512

75. Seifert T, Brassard P, Wissenberg M, Rasmussen P, Nordby P, Stallknecht $\mathrm{B}$, et al. Endurance training enhances BDNF release from the human 
brain. Am J Physiol Regul Integr Comp Physiol. (2009) 298:R372-7. doi: 10.1152/ajpregu.00525.2009

76. Klein AB, Williamson R, Santini MA, Clemmensen C, Ettrup A, Rios $\mathrm{M}$, et al. Blood BDNF concentrations reflect brain-tissue BDNF levels across species. Int J Neuropsychopharmacol. (2011) 14:347-53. doi: 10.1017/S1461145710000738

77. Chacón-Fernández P, Säuberli K, Colzani M, Moreau T, Ghevaert C, Barde YA. Brain-derived neurotrophic factor in megakaryocytes. J Biol Chem. (2016) 291:9872-81. doi: 10.1074/jbc.M116.720029

78. El-Sayed MS, Ali N, El-Sayed Ali Z. Aggregation and activation of blood platelets in exercise and training. Sports Med. (2005) 35:11-22. doi: 10.2165/00007256-200535010-00002

79. Yáñez-Mó M, Siljander PRM, Andreu Z, Bedina Zavec A, Borràs FE, Buzas EI, et al. Biological properties of extracellular vesicles and their physiological functions. J Extracell Vesicles (2015) 4:27066. doi: 10.3402/jev.v4.27066

80. Ogborn DI, Gardiner PF. Effects of exercise and muscle type on BDNF, NT4/5, and TrKB expression in skeletal muscle. Muscle Nerve (2010) 41:385-91. doi: $10.1002 /$ mus. 21503

81. Pedersen BK, Pedersen M, Krabbe KS, Bruunsgaard H, Matthews VB, Febbraio MA. Role of exercise-induced brain-derived neurotrophic factor production in the regulation of energy homeostasis in mammals. Exp Physiol. (2009) 94:1153-60. doi: 10.1113/expphysiol.2009.048561

82. Matthews VB, Astrom MB, Chan MH, Bruce CR, Krabbe KS, Prelovsek $\mathrm{O}$, et al. Brain-derived neurotrophic factor is produced by skeletal muscle cells in response to contraction and enhances fat oxidation via activation of AMP-activated protein kinase. Diabetologia (2009) 52:1409-18. doi: $10.1007 / \mathrm{s} 00125-009-1364-1$

83. Mousavi K, Jasmin BJ. BDNF is expressed in skeletal muscle satellite cells and inhibits myogenic differentiation. J Neurosci. (2006) 26:5739-49. doi: 10.1523/JNEUROSCI.5398-05.2006

84. Koliatsos VE, Clatterbuck RE, Winslow JW, Cayouette MH, Price DL. Evidence that brain-derived neurotrophic factor is a trophic factor for motor neurons in vivo. Neuron (1993) 10:359-67. doi: 10.1016/0896-6273(93)90326-M

85. Givalois L, Arancibia S, Alonso G, Tapia-Arancibia L. Expression of brain-derived neurotrophic factor and its receptors in the median eminence cells with sensitivity to stress. Endocrinology (2004) 145:4737-47. doi: 10.1210/en.2004-0616

86. Ding Q, Vaynman S, Akhavan M, Ying Z, Gomez-Pinilla F. Insulinlike growth factor I interfaces with brain-derived neurotrophic factor-mediated synaptic plasticity to modulate aspects of exerciseinduced cognitive function. Neuroscience (2006) 140:823-33. doi: 10.1016/j.neuroscience.2006.02.084

87. Trejo JL, Carro E, Torres-Aleman I. Circulating insulin-like growth factor I mediates exercise-induced increases in the number of new neurons in the adult hippocampus. I Neurosci (2001) 21:1628-34. doi: 10.1523/JNEUROSCI.21-05-01628.2001

88. Cheng A, Wan R, Yang JL, Kamimura N, Son TG, Ouyang X, et al. Involvement of PGC-1alpha in the formation and maintenance of neuronal dendritic spines. Nat Commun. (2012) 3:1250. doi: 10.1038/ncomms2238

89. Wrann CD, White JP, Salogiannnis J, Laznik-Bogoslavski D, Wu J, Ma D, et al. Exercise induces hippocampal BDNF through a PGC-1alpha/FNDC5 pathway. Cell Metab. (2013) 18:649-59. doi: 10.1016/j.cmet.2013.0 9.008

90. St-Pierre J, Drori S, Uldry M, Silvaggi JM, Rhee J, Jager S, et al. Suppression of reactive oxygen species and neurodegeneration by the PGC-1 transcriptional coactivators. Cell (2006) 127:397-408. doi: 10.1016/j.cell.2006.09.024

91. Adlard PA, Perreau VM, Pop V, Cotman CW. Voluntary exercise decreases amyloid load in a transgenic model of alzheimer's disease. J Neurosci. (2005) 25:4217-21. doi: 10.1523/JNEUROSCI.0496-05.2005

92. Pang TY, Stam NC, Nithianantharajah J, Howard ML, Hannan AJ. Differential effects of voluntary physical exercise on behavioral and brain-derived neurotrophic factor expression deficits in Huntington's disease transgenic mice. Neuroscience (2006) 141:569-84. doi: 10.1016/j.neuroscience.2006.04.013

93. Praag HV, Shubert T, Zhao C, Gage FH. Exercise enhances learning and hippocampal neurogenesis in aged mice. J Neurosci Official J Soc Neurosci. (2005)25:8680-5. doi: 10.1523/JNEUROSCI.1731-05.2005
94. Duzel E, van Praag H, Sendtner M. Can physical exercise in old age improve memory and hippocampal function? Brain (2016) 139:662-73. doi: 10.1093/brain/awv407

95. Erickson KI, Prakash RS, Voss MW, Chaddock L, Hu L, Morris KS, et al. Aerobic fitness is associated with hippocampal volume in elderly humans. Hippocampus (2009) 19:1030-9. doi: 10.1002/hipo.20547

96. Prakash RS, Voss MW, Erickson KI, Kramer AF. Physical activity and cognitive vitality. Annu Rev Psychol. (2015) 66:769-97. doi: 10.1146/annurev-psych-010814-015249

97. Palmer TD, Willhoite AR, Gage FH. Vascular niche for adult hippocampal neurogenesis. J Comp Neurol. (2000) 425:479-94. doi: 10.1002/10969861(20001002)425:4<479::AID-CNE2>3.0.CO;2-3

98. Kraus RM, Stallings HW, Yeager RC, Gavin TP. Circulating plasma VEGF response to exercise in sedentary and endurance-trained men. J Appl Physiol. (2004) 96:1445-50. doi: 10.1152/japplphysiol.01031.2003

99. Fabel K, Fabel K, Tam B, Kaufer D, Baiker A, Simmons N, et al. VEGF is necessary for exercise-induced adult hippocampal neurogenesis. Eur J Neurosci. (2003) 18:2803-12. doi: 10.1111/j.1460-9568.2003.03041.x

100. Gomez-Pinilla F, Ying Z, Opazo P, Roy RR, Edgerton VR. Differential regulation by exercise of BDNF and NT-3 in rat spinal cord and skeletal muscle. Eur J Neurosci. (2001) 13:1078-84. doi: 10.1046/j.0953-816x.2001.01484.x

101. McCullough MJ, Peplinski NG, Kinnell KR, Spitsbergen JM. Glial cell linederived neurotrophic factor protein content in rat skeletal muscle is altered by increased physical activity in vivo and in vitro. Neuroscience (2011) 174:234-44. doi: 10.1016/j.neuroscience.2010.11.016

102. Tajiri N, Yasuhara T, Shingo T, Kondo A, Yuan W, Kadota T, et al. Exercise exerts neuroprotective effects on Parkinson's disease model of rats. Brain Res. (2010) 1310:200-7. doi: 10.1016/j.brainres.2009.10.075

103. Ying Z, Roy RR, Edgerton VR, Gomez-Pinilla F. Voluntary exercise increases neurotrophin-3 and its receptor TrkC in the spinal cord. Brain Res. (2003) 987:93-9. doi: 10.1016/S0006-8993(03)03258-X

104. Phillips C, Baktir MA, Srivatsan M, Salehi A. Neuroprotective effects of physical activity on the brain: a closer look at trophic factor signaling. Front Cell Neurosci. (2014) 8:170. doi: 10.3389/fncel.2014.00170

105. Febbraio MA, Hiscock N, Sacchetti M, Fischer CP, Pedersen BK. Interleukin6 is a novel factor mediating glucose homeostasis during skeletal muscle contraction. Diabetes (2004) 53:1643-8. doi: 10.2337/diabetes.53.7.1643

106. Catoire M, Mensink M, Kalkhoven E, Schrauwen P, Kersten S. Identification of human exercise-induced myokines using secretome analysis. Physiol Genomics (2014) 46:256-67. doi: 10.1152/physiolgenomics.00174.2013

107. Raschke S, Eckardt K, Bjorklund Holven K, Jensen J, Eckel J. Identification and validation of novel contraction-regulated myokines released from primary human skeletal muscle cells. PLoS ONE (2013) 8:e62008. doi: 10.1371/journal.pone.0062008

108. Scheler $M$, Irmler $M$, Lehr $S$, Hartwig $S$, Staiger $H$, Al-Hasani $H$, et al. Cytokine response of primary human myotubes in an in vitro exercise model. Am J Physiol Cell Physiol. (2013) 305:C877-886. doi: 10.1152/ajpcell.00043.2013

109. Norheim F, Raastad T, Thiede B, Rustan AC, Drevon CA, Haugen F. Proteomic identification of secreted proteins from human skeletal muscle cells and expression in response to strength training. Am J Physiol Endocrinol Metab. (2011) 301:E1013-21. doi: 10.1152/ajpendo.00326.2011

110. Roca-Rivada A, Al-Massadi O, Castelao C, Senin LL, Alonso J, Seoane LM, et al. Muscle tissue as an endocrine organ: comparative secretome profiling of slow-oxidative and fast-glycolytic rat muscle explants and its variation with exercise. J Proteomics (2012) 75:5414-25. doi: 10.1016/j.jprot.2012.06.037

111. Pourteymour $S$, Eckardt $K$, Holen $T$, Langleite $T$, Lee $S$, Jensen $J$, et al. Global mRNA sequencing of human skeletal muscle: search for novel exercise-regulated myokines. Mol Metab. (2017) 6:352-65. doi: 10.1016/j.molmet.2017.01.007

112. Schnyder S, Handschin C. Skeletal muscle as an endocrine organ: PGC- $1 \alpha$, myokines and exercise. Bone (2015) 80:115-25. doi: 10.1016/j.bone.2015.02.008

113. Roberts LD, Bostrom P, O'Sullivan JF, Schinzel RT, Lewis GD, Dejam A, et al. $\beta$-Aminoisobutyric acid induces browning of white fat and hepatic betaoxidation and is inversely correlated with cardiometabolic risk factors. Cell Metab. (2014) 19:96-108. doi: 10.1016/j.cmet.2013.12.003 
114. Moon HY, Becke A, Berron D, Becker B, Sah N, Benoni G, et al. Runninginduced systemic cathepsin B secretion is associated with memory function. Cell Metab. (2016) 24:332-40. doi: 10.1016/j.cmet.2016.05.025

115. Morland C, Andersson KA, Haugen OP, Hadzic A, Kleppa L, Gille A, et al. Exercise induces cerebral VEGF and angiogenesis via the lactate receptor HCAR1. Nat Commun. (2017) 8:15557. doi: 10.1038/ncomms15557

116. Sleiman SF, Henry J, Al-Haddad R, El Hayek L, Abou Haidar E, Stringer $\mathrm{T}$, et al. Exercise promotes the expression of brain derived neurotrophic factor (BDNF) through the action of the ketone body $\beta$-hydroxybutyrate. Elife (2016) 5:e15092. doi: 10.7554/eLife.15092

117. Bookout AL, de Groot MH, Owen BM, Lee S, Gautron L, Lawrence HL, et al. FGF21 regulates metabolism and circadian behavior by acting on the nervous system. Nat Med. (2013) 19:1147-52. doi: 10.1038/nm.3249

118. Kim KH, Kim SH, Min YK, Yang HM, Lee JB, Lee MS. Acute exercise induces FGF21 expression in mice and in healthy humans. PLoS ONE (2013) 8:e63517. doi: 10.1371/journal.pone.0063517

119. Owen BM, Ding X, Morgan DA, Coate KC, Bookout AL, Rahmouni $\mathrm{K}$, et al. FGF21 acts centrally to induce sympathetic nerve activity, energy expenditure, and weight loss. Cell Metab. (2014) 20:670-7. doi: 10.1016/j.cmet.2014.07.012

120. Carro E, Nunez A, Busiguina S, Torres-Aleman I. Circulating insulin-like growth factor I mediates effects of exercise on the brain. J Neurosci (2000) 20:2926-33. doi: 10.1523/JNEUROSCI.20-08-02926.2000

121. Agudelo LZ, Femenia T, Orhan F, Porsmyr-Palmertz M, Goiny M, Martinez-Redondo V, et al. Skeletal muscle PGC-1 $\alpha 1$ modulates kynurenine metabolism and mediates resilience to stress-induced depression. Cell (2014) 159:33-45. doi: 10.1016/j.cell.2014.07.051

122. Schlittler M, Goiny M, Agudelo LZ, Venckunas T, Brazaitis M, Skurvydas $A$, et al. Endurance exercise increases skeletal muscle kynurenine aminotransferases and plasma kynurenic acid in humans. Am J Physiol Cell Physiol. (2016) 310:C836-40. doi: 10.1152/ajpcell.00053.2016

123. Ehlen JC, Brager AJ, Baggs J, Pinckney L, Gray CL, DeBruyne JP, et al. Bmal1 function in skeletal muscle regulates sleep. Elife (2017) 6:e26557. doi: 10.7554/eLife.26557

124. Ferrer-Martinez A, Ruiz-Lozano P, Chien KR. Mouse PeP: a novel peroxisomal protein linked to myoblast differentiation and development. Dev Dyn. (2002) 224:154-67. doi: 10.1002/dvdy.10099

125. Teufel A, Malik N, Mukhopadhyay M, Westphal H. Frcp1 and Frcp2, two novel fibronectin type III repeat containing genes. Gene (2002) 297:79-83. doi: 10.1016/S0378-1119(02)00828-4

126. Bostrom P, Wu J, Jedrychowski MP, Korde A, Ye L, Lo JC, et al. A PGC1- $\alpha$ dependent myokine that drives brown-fat-like development of white fat and thermogenesis. Nature (2012) 481:463-8. doi: 10.1038/nature10777

127. Jedrychowski MP, Wrann CD, Paulo JA, Gerber KK, Szpyt J, Robinson $M M$, et al. Detection and Quantitation of Circulating Human Irisin by Tandem Mass Spectrometry. Cell Metab (2015) 22:734-40. doi: 10.1016/j.cmet.2015.08.001

128. Lee P, Linderman JD, Smith S, Brychta RJ, Wang J, Idelson C, et al. Irisin and FGF21 are cold-induced endocrine activators of brown fat function in humans. Cell Metab. (2014) 19:302-9. doi: 10.1016/j.cmet.2013.1 2.017

129. Perakakis N, Triantafyllou GA, Fernandez-Real JM, Huh JY, Park KH, Seufert J, et al. Physiology and role of irisin in glucose homeostasis. Nat Rev Endocrinol. (2017) 13:324-37. doi: 10.1038/nrendo.2016.221

130. Hashemi MS, Ghaedi K, Salamian A, Karbalaie K, Emadi-Baygi M, Tanhaei $S$, et al. Fndc5 knockdown significantly decreased neural differentiation rate of mouse embryonic stem cells. Neuroscience (2013) 231:296-304. doi: 10.1016/j.neuroscience.2012.11.041

131. Zhang W, Chang L, Zhang C, Zhang R, Li Z, Chai B, et al. Central and peripheral irisin differentially regulate blood pressure. Cardiovasc Drugs Ther. (2015) 29:121-7. doi: 10.1007/s10557-015-6580-y

132. Turk V, Stoka V, Vasiljeva O, Renko M, Sun T, Turk B, et al. Cysteine cathepsins: from structure, function and regulation to new frontiers. Biochim Biophys Acta (2012) 1824:68-88. doi: 10.1016/j.bbapap.2011.10.002

133. Aggarwal N, Sloane BF. Cathepsin B: multiple roles in cancer. Proteomics Clin Appl. (2014) 8:427-37. doi: 10.1002/prca.201300105

134. Theocharis AD, Gialeli C, Bouris P, Giannopoulou E, Skandalis SS, Aletras $\mathrm{AJ}$, et al. Cell-matrix interactions: focus on proteoglycan-proteinase interplay and pharmacological targeting in cancer. FEBS J. (2014) 281:5023-42. doi: $10.1111 /$ febs.12927

135. Lauritzen KH, Morland C, Puchades M, Holm-Hansen S, Hagelin EM, Lauritzen F, et al. Lactate receptor sites link neurotransmission, neurovascular coupling, and brain energy metabolism. Cereb Cortex (2014) 24:2784-95. doi: 10.1093/cercor/bht136

136. Wang L, Chopp M, Gregg SR, Zhang RL, Teng H, Jiang A, et al. Neural progenitor cells treated with EPO induce angiogenesis through the production of VEGF. J Cereb Blood Flow Metab. (2008) 28:1361-8. doi: $10.1038 /$ jcbfm.2008.32

137. Hall CN, Reynell C, Gesslein B, Hamilton NB, Mishra A, Sutherland BA, et al. Capillary pericytes regulate cerebral blood flow in health and disease. Nature (2014) 508:55-60. doi: 10.1038/nature13165

138. Craft LL, Perna FM. The benefits of exercise for the clinically depressed. Prim Care Companion J Clin Psychiatry (2004) 6:104-11. doi: 10.4088/PCC.v06n0301

139. Josefsson T, Lindwall M, Archer T. Physical exercise intervention in depressive disorders: meta-analysis and systematic review. Scand J Med Sci Sports (2014) 24:259-72. doi: 10.1111/sms.12050

140. Reus GZ, Jansen K, Titus S, Carvalho AF, Gabbay V, Quevedo J. Kynurenine pathway dysfunction in the pathophysiology and treatment of depression: Evidences from animal and human studies. J Psychiatr Res (2015) 68:316-28. doi: 10.1016/j.jpsychires.2015.05.007

141. Schwarcz R, Bruno JP, Muchowski PJ, Wu HQ. Kynurenines in the mammalian brain: when physiology meets pathology. Nat Rev Neurosci. (2012) 13:465-77. doi: 10.1038/nrn3257

142. Cotman CW, Berchtold NC, Christie L-A. Exercise builds brain health: key roles of growth factor cascades and inflammation. Trends in Neurosciences (2007) 30:464-72. doi: 10.1016/j.tins.2007.06.011

143. Di Benedetto S, Müller L, Wenger E, Düzel S, Pawelec G. Contribution of neuroinflammation and immunity to brain aging and the mitigating effects of physical and cognitive interventions. NeurosciBiobehavl Rev. (2017) 75:114-28. doi: 10.1016/j.neubiorev.2017.01.044

144. Svensson K, Albert V, Cardel B, Salatino S, Handschin C. Skeletal muscle PGC-1 $\alpha$ modulates systemic ketone body homeostasis and ameliorates diabetic hyperketonemia in mice. Faseb J. (2016) 30:1976-86. doi: 10.1096/fj.201500128

145. Koppel I, Timmusk T. Differential regulation of Bdnf expression in cortical neurons by class-selective histone deacetylase inhibitors. Neuropharmacology (2013) 75:106-15. doi: 10.1016/j.neuropharm.2013.07.015

146. Chavan R, Feillet C, Costa SS, Delorme JE, Okabe T, Ripperger JA, et al. Liverderived ketone bodies are necessary for food anticipation. Nat Commun. (2016) 7:10580. doi: 10.1038/ncomms10580

147. Brown RE, Basheer R, McKenna JT, Strecker RE, McCarley RW Control of sleep and wakefulness. Physiol Rev. (2012) 92:1087-187. doi: 10.1152/physrev.00032.2011

148. Partch CL, Green CB, Takahashi JS. Molecular architecture of the mammalian circadian clock. Trends Cell Biol. (2014) 24:90-9. doi: $10.1016 /$ j.tcb.2013.07.002

149. Naylor E, Bergmann BM, Krauski K, Zee PC, Takahashi JS, Vitaterna MH, et al. The circadian clock mutation alters sleep homeostasis in the mouse. $J$ Neurosci. (2000) 20:8138-43. doi: 10.1523/JNEUROSCI.20-21-08138.2000

150. Patke A, Murphy PJ, Onat OE, Krieger AC, Ozcelik T, Campbell SS, et al. Mutation of the human circadian clock gene CRY1 in familial delayed sleep phase disorder. Cell (2017) 169:203-15 e213. doi: 10.1016/j.cell.2017.03.027

151. Laposky A, Easton A, Dugovic C, Walisser J, Bradfield C, Turek F. Deletion of the mammalian circadian clock gene BMAL1/Mop3 alters baseline sleep architecture and the response to sleep deprivation. Sleep (2005) 28:395-409. doi: 10.1093/sleep/28.4.395

152. Dyar KA, Ciciliot S, Wright LE, Bienso RS, Tagliazucchi GM, Pate $\mathrm{VR}$, et al. Muscle insulin sensitivity and glucose metabolism are controlled by the intrinsic muscle clock. Mol Metab. (2014) 3:29-41. doi: 10.1016/j.molmet.2013.10.005

153. Harfmann BD, Schroder EA, Kachman MT, Hodge BA, Zhang X, Esser KA. Muscle-specific loss of Bmall leads to disrupted tissue glucose metabolism and systemic glucose homeostasis. Skelet Muscle (2016) 6:12. doi: 10.1186/s13395-016-0082-x 
154. McDearmon EL, Patel KN, Ko CH, Walisser JA, Schook AC, Chong $\mathrm{JL}$, et al. Dissecting the functions of the mammalian clock protein BMAL1 by tissue-specific rescue in mice. Science (2006) 314:1304-8. doi: 10.1126/science.1132430

155. Carey AL, Steinberg GR, Macaulay SL, Thomas WG, Holmes AG, Ramm G, et al. Interleukin-6 increases insulin-stimulated glucose disposal in humans and glucose uptake and fatty acid oxidation in vitro via AMP-activated protein kinase. Diabetes (2006) 55:2688-97. doi: 10.2337/db05-1404

156. Ellingsgaard H, Hauselmann I, Schuler B, Habib AM, Baggio LL, Meier DT, et al. Interleukin- 6 enhances insulin secretion by increasing glucagon-like peptide-1 secretion from L cells and alpha cells. Nat Med. (2011) 17:1481-9. doi: $10.1038 / \mathrm{nm} .2513$

157. Wueest S, Item F, Boyle CN, Jirkof P, Cesarovic N, Ellingsgaard H, et al. Interleukin- 6 contributes to early fasting-induced free fatty acid mobilization in mice. Am J Physiol Regul Integr Comp Physiol. (2014) 306:R861-7. doi: 10.1152/ajpregu.00533.2013

158. Pedersen BK, Febbraio MA. Muscles, exercise and obesity: skeletal muscle as a secretory organ. Nat Rev Endocrinol. (2012) 8:457-65. doi: 10.1038/nrendo.2012.49

159. Banks WA. Blood-brain barrier transport of cytokines: a mechanism for neuropathology. Curr Pharm Des. (2005) 11:973-84. doi: $10.2174 / 1381612053381684$

160. Calabrese F, Rossetti AC, Racagni G, Gass P, Riva MA, Molteni R. Brain-derived neurotrophic factor: a bridge between inflammation and neuroplasticity. Front Cell Neurosci. (2014) 8:430. doi: 10.3389/fncel.2014.00430

161. Galic MA, Riazi K, Pittman QJ. Cytokines and brain excitability. Front Neuroendocrinol. (2012) 33:116-25. doi: 10.1016/j.yfrne.2011.12.002

162. Fisher FM, Maratos-Flier E. Understanding the Physiology of FGF21. Annu Rev Physiol. (2016) 78:223-41. doi: 10.1146/annurev-physiol-021115-105339

163. Hsuchou H, Pan W, Kastin AJ. The fasting polypeptide FGF21 can enter brain from blood. Peptides (2007) 28:2382-6. doi: 10.1016/j.peptides.2007.10.007

164. Tan BK, Hallschmid M, Adya R, Kern W, Lehnert H, Randeva HS. Fibroblast growth factor 21 (FGF21) in human cerebrospinal fluid: relationship with plasma FGF21 and body adiposity. Diabetes (2011) 60:2758-62. doi: $10.2337 / \mathrm{db} 11-0672$

165. Sa-Nguanmoo P, Tanajak P, Kerdphoo S, Satjaritanun P, Wang X, Liang G, et al. FGF21 improves cognition by restored synaptic plasticity, dendritic spine density, brain mitochondrial function and cell apoptosis in obese-insulin resistant male rats. Horm Behav. (2016) 85:86-95. doi: 10.1016/j.yhbeh.2016.08.006

166. Guridi M, Tintignac LA, Lin S, Kupr B, Castets P, Ruegg MA. Activation of mTORC1 in skeletal muscle regulates whole-body metabolism through FGF21. Sci Signal (2015) 8:ra113. doi: 10.1126/scisignal.aab3715

167. Harris LA, Skinner JR, Shew TM, Pietka TA, Abumrad NA, Wolins NE. Perilipin 5-driven lipid droplet accumulation in skeletal muscle stimulates the expression of fibroblast growth factor 21. Diabetes (2015) 64:2757-68. doi: $10.2337 / \mathrm{db} 14-1035$

168. Izumiya $\mathrm{Y}$, Bina HA, Ouchi N, Akasaki Y, Kharitonenkov A, Walsh K. FGF21 is an Akt-regulated myokine. FEBS Lett. (2008) 582:3805-10. doi: 10.1016/j.febslet.2008.10.021

169. Keipert S, Ost M, Johann K, Imber F, Jastroch M, van Schothorst EM, et al. Skeletal muscle mitochondrial uncoupling drives endocrine cross-talk through the induction of FGF21 as a myokine. Am J Physiol Endocrinol Metab. (2014) 306:E469-82. doi: 10.1152/ajpendo.00330.2013

170. Pereira RO, Tadinada SM, Zasadny FM, Oliveira KJ, Pires KMP, Olvera A, et al. OPA1 deficiency promotes secretion of FGF21 from muscle that prevents obesity and insulin resistance. EMBO J. (2017) 36:2126-45. doi: 10.15252/embj.201696179

171. Estall JL, Ruas JL, Choi CS, Laznik D, Badman M, Maratos-Flier E, et al. PGC-1 $\alpha$ negatively regulates hepatic FGF21 expression by modulating the heme/Rev-Erb $(\alpha)$ axis. Proc Natl Acad Sci USA. (2009) 106:22510-5. doi: 10.1073/pnas.0912533106

172. Wu J, Ruas JL, Estall JL, Rasbach KA, Choi JH, Ye L, et al. The unfolded protein response mediates adaptation to exercise in skeletal muscle through a PGC-1 $\alpha /$ ATF6 $\alpha$ complex. Cell Metab. (2011) 13:160-9. doi: 10.1016/j.cmet.2011.01.003
173. Cianferotti L, Brandi ML. Muscle-bone interactions: basic and clinical aspects. Endocrine (2014) 45:165-77. doi: 10.1007/s12020-013-0026-8

174. Karasik D, Kiel DP. Evidence for pleiotropic factors in genetics of the musculoskeletal system. Bone (2010) 46:1226-37. doi: 10.1016/j.bone.2010.01.382

175. Novotny SA, Warren GL, Hamrick MW. Aging and the muscle-bone relationship. Physiology (2015) 30:8-16. doi: 10.1152/physiol.00033.2014

176. Brotto M, Bonewald L. Bone and muscle: Interactions beyond mechanical. Bone (2015) 80:109-14. doi: 10.1016/j.bone.2015.02.010

177. Lee NK, Sowa H, Hinoi E, Ferron M, Ahn JD, Confavreux C, et al. Endocrine regulation of energy metabolism by the skeleton. Cell (2007) 130:456-69. doi: 10.1016/j.cell.2007.05.047

178. Mera P, Laue K, Ferron M, Confavreux C, Wei J, Galan-Diez M, et al. Osteocalcin signaling in myofibers is necessary and sufficient for optimum adaptation to exercise. Cell Metab. (2016) 23:1078-92. doi: 10.1016/j.cmet.2016.05.004

179. Mosialou I, Shikhel S, Liu JM, Maurizi A, Luo N, He Z, et al. MC4Rdependent suppression of appetite by bone-derived lipocalin 2. Nature (2017) 543:385-90. doi: 10.1038/nature21697

180. Flo TH, Smith KD, Sato S, Rodriguez DJ, Holmes MA, Strong RK, et al. Lipocalin 2 mediates an innate immune response to bacterial infection by sequestrating iron. Nature (2004) 432:917-21. doi: 10.1038/nature03104

181. Furrer R, Eisele PS, Schmidt A, Beer M, Handschin C. Paracrine cross-talk between skeletal muscle and macrophages in exercise by PGC-1 $\alpha$-controlled BNP. Sci Rep. (2017) 7:40789. doi: 10.1038/srep40789

182. Yau SY, Li A, Hoo RL, Ching YP, Christie BR, Lee TM, et al. Physical exerciseinduced hippocampal neurogenesis and antidepressant effects are mediated by the adipocyte hormone adiponectin. Proc Natl Acad Sci USA. (2014) 111:15810-5. doi: 10.1073/pnas.1415219111

183. Quinn LS, Strait-Bodey L, Anderson BG, Argiles JM, Havel PJ. Interleukin15 stimulates adiponectin secretion by 3T3-L1 adipocytes: evidence for a skeletal muscle-to-fat signaling pathway. Cell Biol Int. (2005) 29:449-57. doi: 10.1016/j.cellbi.2005.02.005

184. Longo VD, Panda S. Fasting, circadian rhythms, and timerestricted feeding in healthy lifespan. Cell Metab. (2016) 23:1048-59. doi: 10.1016/j.cmet.2016.06.001

185. Bass J, Lazar MA. Circadian time signatures of fitness and disease. Science (2016) 354:994-9. doi: 10.1126/science.aah4965

186. Bedrosian TA, Fonken LK, Nelson RJ. Endocrine effects of circadian disruption. Annu Rev Physiol. (2016) 78:109-31. doi: 10.1146/annurev-physiol-021115-105102

187. McClung CA. Circadian genes, rhythms and the biology of mood disorders. Pharmacol Ther. (2007) 114:222-32. doi: 10.1016/j.pharmthera.2007.02.003

188. Wulff K, Gatti S, Wettstein JG, Foster RG. Sleep and circadian rhythm disruption in psychiatric and neurodegenerative disease. Nat Rev Neurosci. (2010) 11:589-99. doi: 10.1038/nrn2868

189. Andrews JL, Zhang X, McCarthy JJ, McDearmon EL, Hornberger TA, Russell B, et al. CLOCK and BMAL1 regulate MyoD and are necessary for maintenance of skeletal muscle phenotype and function. Proc Natl Acad Sci USA. (2010) 107:19090-5. doi: 10.1073/pnas.1014523107

190. Loizides-Mangold U, Perrin L, Vandereycken B, Betts JA, Walhin J-P, Templeman I, et al. Lipidomics reveals diurnal lipid oscillations in human skeletal muscle persisting in cellular myotubes cultured in vitro. Proc Natl Acad Sci USA. (2017) 114:E8565-74. doi: 10.1073/pnas.1705821114

191. Woldt E, Sebti Y, Solt LA, Duhem C, Lancel S, Eeckhoute J, et al. Rev-erb- $\alpha$ modulates skeletal muscle oxidative capacity by regulating mitochondrial biogenesis and autophagy. Nat Med. (2013) 19:1039-46. doi: $10.1038 / \mathrm{nm} .3213$

192. Aoyama S, Shibata S. The role of circadian rhythms in muscular and osseous physiology and their regulation by nutrition and exercise. Front Neurosci. (2017) 11:63. doi: 10.3389/fnins.2017.00063

193. Wolff G, Esser KA. Scheduled exercise phase shifts the circadian clock in skeletal muscle. Med Sci Sports Exerc. (2012) 44:1663-70. doi: 10.1249/MSS.0b013e318255cf4c

194. Perrin L, Loizides-Mangold U, Skarupelova S, Pulimeno P, Chanon S, Robert $\mathrm{M}$, et al. Human skeletal myotubes display a cell-autonomous circadian clock implicated in basal myokine secretion. Mol Metab. (2015) 4:834-45. doi: 10.1016/j.molmet.2015.07.009 
195. Liu C, Li S, Liu T, Borjigin J, Lin JD. Transcriptional coactivator PGC$1 \alpha$ integrates the mammalian clock and energy metabolism. Nature (2007) 447:477-81. doi: 10.1038/nature05767

196. Eckel-Mahan K, Sassone-Corsi P. Metabolism and the circadian clock converge. Physiol Rev. (2013) 93:107-35. doi: 10.1152/physrev.00016.2012

197. Gerstner JR, Lyons LC, Wright KP, Loh DH, Rawashdeh O, Eckel-Mahan $\mathrm{KL}$, et al. Cycling behavior and memory formation. J Neurosci. (2009) 29:12824-30. doi: 10.1523/JNEUROSCI.3353-09.2009

198. Jilg A, Lesny S, Peruzki N, Schwegler H, Selbach O, Dehghani F, et al. Temporal dynamics of mouse hippocampal clock gene expression support memory processing. Hippocampus (2010) 20:377-88. doi: 10.1002/hipo.20637

199. Marpegan L, Swanstrom AE, Chung K, Simon T, Haydon PG, Khan SK, et al. Circadian regulation of ATP release in astrocytes. J Neurosci.(2011) 31:8342-50. doi: 10.1523/JNEUROSCI.6537-10.2011

200. Musiek ES, Lim MM, Yang G, Bauer AQ, Qi L, Lee Y, et al. Circadian clock proteins regulate neuronal redox homeostasis and neurodegeneration. J Clin Invest. (2013) 123:5389-400. doi: 10.1172/JCI70317
201. Valnegri P, Khelfaoui M, Dorseuil O, Bassani S, Lagneaux C, Gianfelice A, et al. A circadian clock in hippocampus is regulated by interaction between oligophrenin-1 and Rev-erbalpha. Nat Neurosci. (2011) 14:1293301. doi: $10.1038 / \mathrm{nn} .2911$

202. Catoire M, Kersten S. The search for exercise factors in humans. FASEB J. (2015) 29:1615-28. doi: 10.1096/fj.14-2 63699

Conflict of Interest Statement: The authors declare that the research was conducted in the absence of any commercial or financial relationships that could be construed as a potential conflict of interest.

Copyright $(2018$ Delezie and Handschin. This is an open-access article distributed under the terms of the Creative Commons Attribution License (CC BY). The use, distribution or reproduction in other forums is permitted, provided the original author(s) and the copyright owner(s) are credited and that the original publication in this journal is cited, in accordance with accepted academic practice. No use, distribution or reproduction is permitted which does not comply with these terms. 